\title{
THERMAL CONVERSION OF MUNICIPAL WASTE INTO ENERGY: PROSPECTS FOR THE SUB-CARPATHIA
}

\author{
Łukasz Jurczyk ${ }^{1}$, Justyna Koc-Jurczyk ${ }^{1}$ \\ 1 University of Rzeszow, Faculty of Biology and Agriculture, Department of Biological Basis of Agriculture and \\ Environmental Education, 1b Cwiklinskiej St., 35-601 Rzeszow, Poland, e-mail: jjurczyk@ur.edu.pl
}

Received: 2016.12.23

Accepted: 2017.01.19

Published: 2017.03.01

\begin{abstract}
Dumping municipal waste is the least expensive and most commonly used method of disposing solid waste. However, there is an alternative, two-in-one, solution: conversion of waste to energy. Non-recyclable waste can be turned into heat, electric power or fuel using various processes, such as gasification, pyrolysis or anaerobic fermentation. This is how residual waste can serve as sustainable local source of energy, additionally, contributing to environmental protection and, to a significant extent, energy supply security.
\end{abstract}

Keywords: municipal waste, waste-to-energy, Sub-Carpathia

\section{INTRODUCTION}

People produce waste as a part of both domestic and commercial activities. Due to the global population the growth and the pursuit of the economic development model based on industrialization, consumption and rapid urbanization, we produce so much municipal waste, and at such a concentration, that the nature cannot deal with the problem by itself any longer. This is why we need to help it by managing and neutralizing wastes properly, working towards sustainable development. According to Kostecka [2013] and Kostecka et al. [2016], it is the man who has to accept the burden of managing and neutralizing the wastes that are produced and, working towards realization of sustainable development, he has to be able to evaluate his place in the society, also in terms of participation in developing correct waste management .

According to European statistics, there are huge differences between quantities of municipal wastes produced by individual states; for instance, $759 \mathrm{~kg}$ per capita in Denmark vs. just $272 \mathrm{~kg}$ in Poland and Romania in 2014. These contrasts come from remarkable, or often dramatic, differences not only in levels of consumption but also in waste collection (including sorting) and further handling performance. The following review of per capita municipal waste accumulation in European states (Fig. 1) shows that these quantities have grown over the recent 20 years in 17 of the 31 states, including Malta (2.2\%) and Denmark $(2.0 \%)$ as the "leaders".

The framework EU Directive [2008/98/EC] defines main rules for handling wastes, including the requirements for avoidance of adverse environmental effects protection of human health, correct addressing the "waste handling hierarchy" in business plans, or, based on the "polluter pays" principle, the requirement that waste neutralization costs are paid by owners (current or former) or users of waste. Wastes should be collected selectively, where technically feasible and if practical from the economic and environmental points of view. Based on the "waste handling hierarchy", in order to develop "recycling societies", EU Member States should promote re-use of wastes (such as recycled paper) and, unless unavoidable, should not support dumping or, as the next alternative, combustion of such wastes. To promote reduction of greenhouse gas emission from dumps, they should promote selective collection of wastes and conversion of biological ones into environmentally safe compost. 


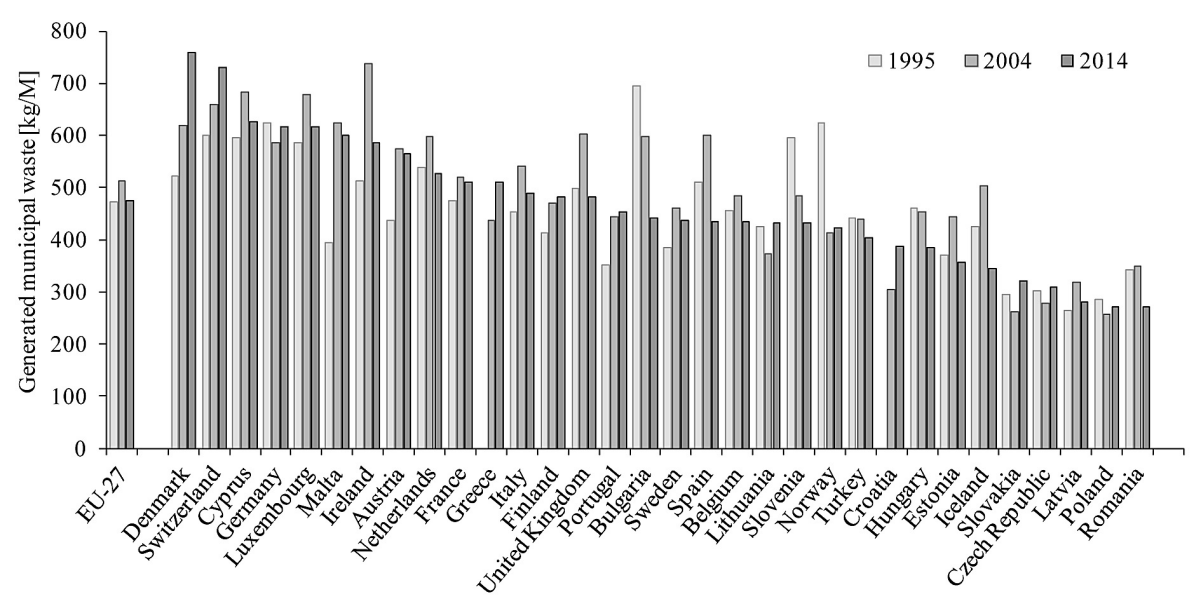

Figure 1. Quantities of municipal waste produced in Europe in 1995, 2004 and 2014 (countries listed by their ranking in 2014 ac. to www.ec.europa.eu)

According to EU Directive, the "management (or handling) of waste" means collection, transport, recovery and neutralization including supervision. "Selective collection" means waste segregation by types to facilitate adequate processing and "recovery" refers to any process leading to reuse of a recycled material instead of a new material (Appendix II to the Directive, which elaborates on the latter definition, contains a list of recovery processes, such as conversion of waste into fuel or recovery of non-solvent organic substances). Next, "neutralization" means any process other than recovery (even if a substance or energy is, in fact, recovered as a "byproduct" of the process), such as storage on dedicated dumps (in contained spaces covered and sealed off one from another and from the environment) or thermal conversion on land (see Appendix I for the complete list). Finally, "processing" means any recovery and/or neutralization including preparations.

This paper aims to find out whether the thermal processing of municipal waste can be regarded as serving the goal of "sustainable development". Specific emphasis was placed on evaluation of prospects for implementing such solutions in the Sub-Carpathia.

\section{CONVERSION OF WASTE INTO ENERGY}

In a short term, dumping municipal waste is the cheapest and, hence, most common method of waste disposing . Like any waste management facility, dump sites are unwelcomed to local communities. Inadequate (non-compliant) storage can contribute to environmental pollution or affect human health or safety of employees. Further, storing waste can give a global effect: according to estimates, greenhouse gas emission from decomposing solid municipal waste grew by $54 \%$ between 1990 and 2008 [Tan et al. 2015]. Even if some proposed storage methods claim they can provide for "dump sustainability", meaning ability to store highly processed materials until re-use, they will remain unfeasible for much longer because of their yet unresolved flaws (such as seepage) [Jurczyk, Koc-Jurczyk 2014].

Closing non-conforming dumps is proposed as a measure to reduce environmental footprint of waste disposal. Those that will be retained should be upgraded for efficient recovery of methane from anaerobic decomposition of organic matter (representing up to $50 \%$ of the decomposition product gas). According to Tan et al. [2015], a single ton of dry waste can provide $120-150$ $\mathrm{m}^{3}$ of methane, which corresponds to a calorific value of 2,500 MJ/t. This aspect is very important because methane is a much more powerful contributor to the greenhouse effect than carbon dioxide (the product of combustion of methane).

Another recommendation is for avoidance of storing wastes that can be combusted with heat recovery. This is why the waste-to-energy conversion is a feasible alternative to storage and waste can become an alternative source of energy [Tan et al. 2014]. Based on long-term research, non-recyclable waste can be converted into heat, electric power or fuel using such processes as gasification, pyrolysis or methanogenesis. Now, it is important to research into how individual technologies or their combinations can be best used for processing specific types of waste [Chen et al. 2016]. 
The conversion can be based on both biological and thermal systems [Johri et al. 2011]. Many such plants exist in developed countries, such as Japan, Germany, Sweden, Denmark or UK. For instance, Japan, a country that can hardly afford to spare land for dumps, converts more than $80 \%$ of its solid municipal waste into energy (including $10 \%$ of electric power) in its 1,900 combustion plants [Tanaka 2014]. Germany, after the waste management system reform of 1990's, converts $35 \%$ of its waste, dumping as little as $1 \%$. Sweden combusts almost $50 \%$ of its municipal waste and converts waste-derived methane into heat, electric power and fuels [Dahlquist et al. 2011]. Johari et al. [2012] and Noor et al. [2013] studied the potential for using such methane with economic and environmental benefits. They modeled methane production from an existing dump and set up a business case but failed to address its capital and operating expenses. Then, $\mathrm{Ng}$ et al. [2014] concluded that the conversion of municipal waste was unprofitable because of high cost of the combustion, gasification and pyrolysis technologies but their model did not address environmental costs. On the other hand, Tan et al. [2014] suggested that the conversion can be profitable and can contribute to greenhouse gas emission reduction provided that municipal waste is adequately pre-treated. However, the foregoing studies covered a narrow range of conversion technologies: just dumping and combustion.
Only Tan et al. [2015] researched into the conversion from the point of view of holistic sustainable development, taking account of costs and gains in terms of energy, economics and environment ("3E" approach). They found recovery of methane and waste combustion, fermentation and gasification as the best of the technologies at hand. They considered conversion of municipal waste into heat and electric power. Their financial model included costs (capital expenditures and operating expenses including transport) and gains (energy sales, no credits for coal supply, profits on sale of byproducts). And the environmental evaluation included emission of greenhouse gases as part of the conversion and replacement of coal with waste as a renewable energy source (Fig. 2).

As shown in Figure 3, the conversion can be done in 3 ways: by thermal processing, by biological processing and by just storing waste [Tan et al. 2014]. Waste combustion and gasification systems are options for the thermal process producing electric power and heat. Biological processing consists of anaerobic production of methane ready for combustion.

Poland dumps more than $80 \%$ of its municipal waste. We expect completion of 10 large combustion plants with capacity of approx. 1.5 million tons of waste by 2019. It is estimated that in 2020 $50 \%$ of municipal waste will be recycled, $25 \%$ will be mechanically and biologically treated and the rest (3.5 million of the aggregate quantity of

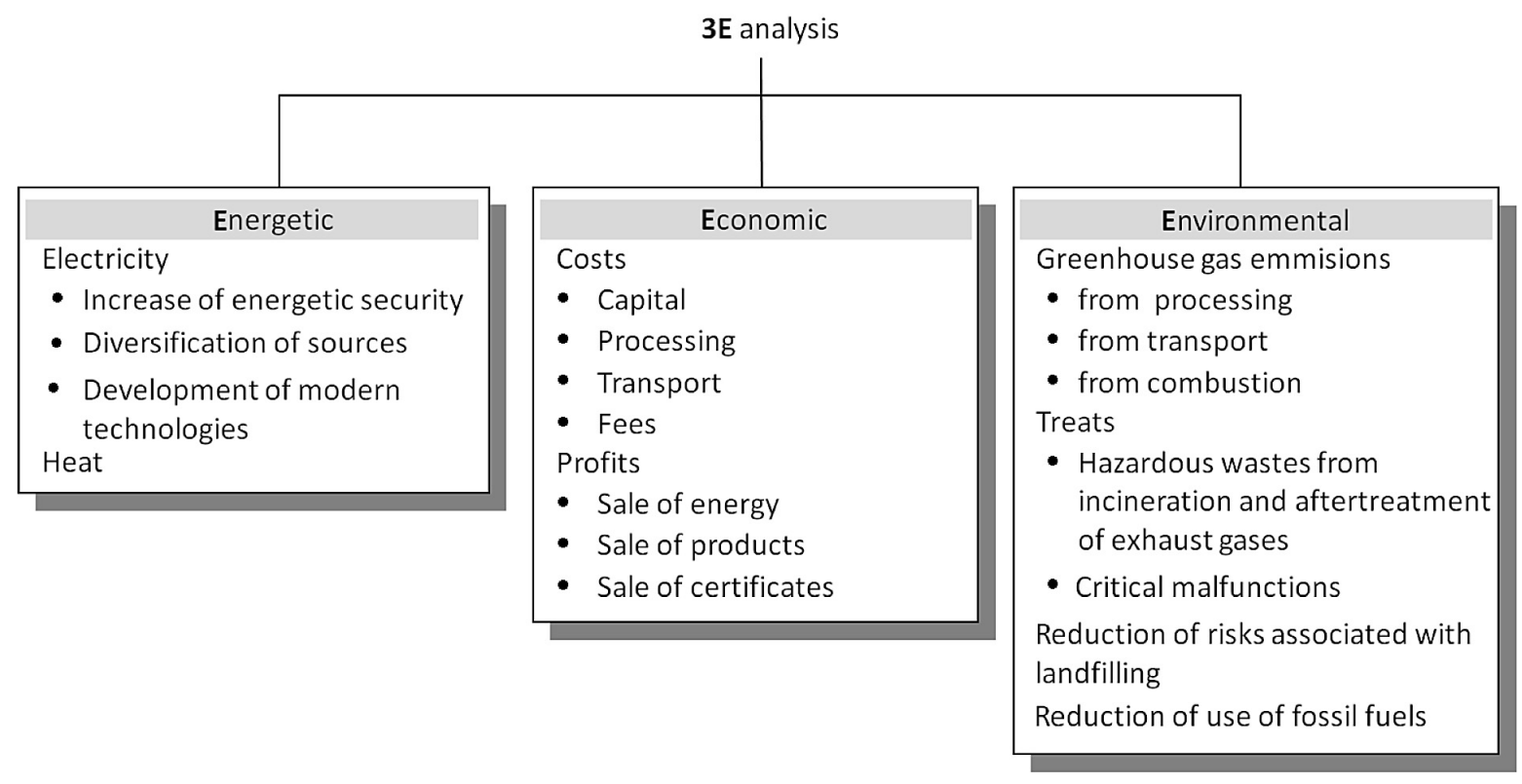

Figure 2. 3E study of the waste-to-energy conversion [Tan et al. 2015] 


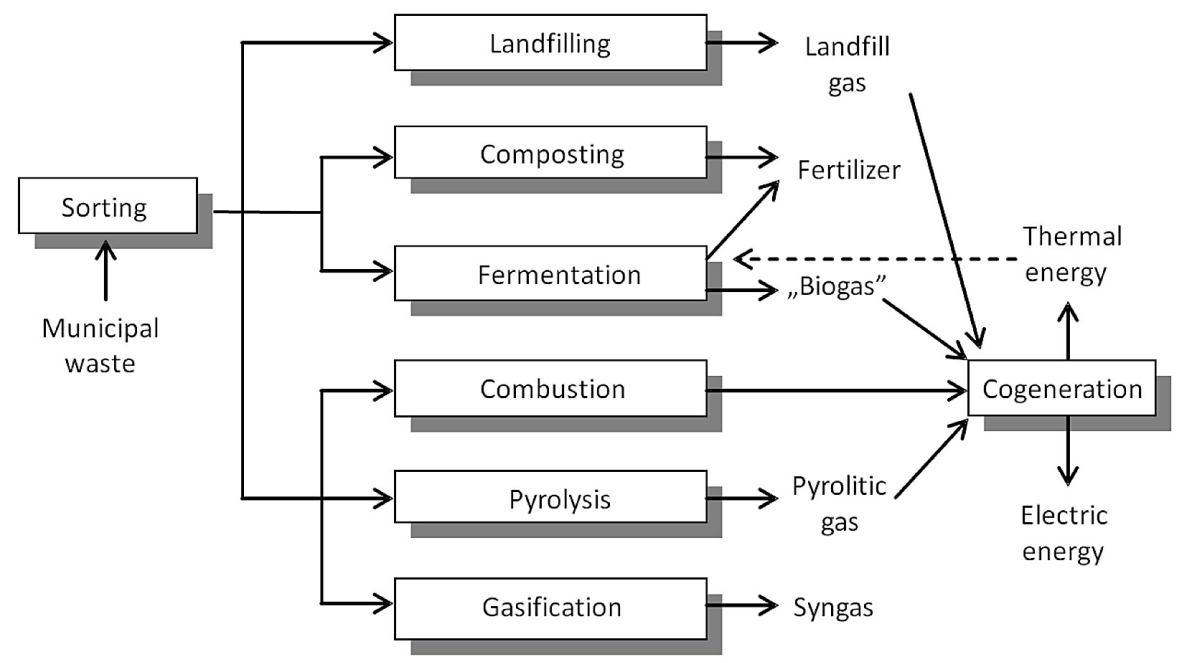

Figure 3. Energy recovery as part of various municipal waste neutralization processes [Tan et al. 2014]

approx. 15 million tons) will be thermally converted [Wojdyga et al. 2014].

While discussing thermal processes applied to wastes, we should first consider the definition of the thermal conversion provided in section 3.1.26 of the Waste Law of 14/12/2012 [Dz.U. 2013 poz. 21]:

a) waste combustion by oxidation;

b) other processes of thermal waste conversion, including pyrolysis, gasification and plasma processes, provided that substances produced in these processes are subsequently combusted.

This means that a process of thermal conversion including its intermediate phases, if any (such as gasification), has to end with combustion. See Table 1 for a detailed process matrix.

\section{WASTE-TO-ENERGY CONVERSION PROSPECTS FOR THE SUB-CARPATHIA}

Much of the local potential for the implementation of the technology depends on demographic and economic factors. The region has more than 2 million inhabitants but only 5 of the 51 towns and cities have populations exceeding 60 thousand. There are no large cities except Rzeszow with a population of 180 thousand (density of almost 1,600 residents $/ \mathrm{km}$ ) and the urban population proportion (41\%) is the smallest one in Poland [GUS, 2015a]. Also the municipal waste production and accumulation rates are the lowest. According to the "Statistical Yearbook" [GUS 2015b], Poland produced approx. 1,033 million tons of municipal waste in 2014, in which the
Sub-Carpathia had a share of 381 thousand tons and was ranked $6^{\text {th }}$ and $3^{\text {rd }}$ from the bottom of the official lists of regions with the smallest overall and per capita $(179 \mathrm{~kg} / \mathrm{y})$, respectively, waste production (Fig. 4). More than one half (54\%) of the waste is mixed, qualified for dumping [GUS 2015b]. Note, however, that - based on life experience - statistical data can err. Only the largest city of the region has a per capita waste accumulation rate of more than $342 \mathrm{~kg} / \mathrm{y}$ [Wójcik 2014].

Residents of multi-apartment estates in Rzeszow dispose of their garbage to $1.1 \mathrm{~m}^{3}$ containers housed in shelters, pre-sorted into "wet" (containing organic matter) mixed waste and "dry" mixed waste fit for further sorting. Residents of single-family houses dispose of "wet" mixed waste into bins of different sizes and "dry" mixed waste (with glass sorted out) into plastic bags [Wójcik 2013]. Also "green" and hazardous wastes can be collected and an outsourced company picks up worn electric and electronic equipment.

Regionalization of the waste management policies in Poland has led to a two-fold decrease in the number of dumps in Poland within a short time: from 803 occupying 2,821 hectares of land in 2009 to 394 with a 1,927-hectare footprint in 2014 [GUS 2015b]. There were 18 dumping sites in the Sub-Carpathia in 2014, but in the Provincial Solid Waste Management Strategy [PGO 2012] only 9 installations, including 3 landfills (Kozodrza, Przemysl and Stalowa Wola), had the status of Regional Municipal Waste Treatment Installations, assigned to 4 regions. As shown in Figure 3, waste in Poland and in the Sub-Carpathia can be converted into energy as follows: 
Table 1. Matrix of thermal processes used for municipal waste processing, products and additional product uses (based on Nadziakiewicz et al. [2012])

\begin{tabular}{|c|c|c|c|c|}
\hline Process & Drying & Carbonification & \multicolumn{2}{|c|}{ Incineration } \\
\hline $\begin{array}{l}\text { Component } \\
\text { processes }\end{array}$ & Evaporation / diffusion & Pyrolysis / degassing & $\begin{array}{c}\text { Gasification (with air or } \\
\text { water as the gasifying } \\
\text { factor) }\end{array}$ & Combustion \\
\hline Fuel conversion & None & \multicolumn{2}{|c|}{ Indirect } & Direct \\
\hline Excess air $(\lambda)$ & Irrelevant & 0 & $<1$ & $>1$ \\
\hline Temperature $\left({ }^{\circ} \mathrm{C}\right)$ & $\begin{array}{c}<105 \\
\text { (consider energy } \\
\text { demand per unit of } \\
\text { weight } / \mathrm{kJ} / \mathrm{kg} \text { dry } \\
\mathrm{mass} / \text { ) }\end{array}$ & $\begin{array}{c}400-700 \\
\text { (low-temperature } \\
\text { carbonization) } \\
900-1000 \text { (high- } \\
\text { temperature } \\
\text { carbonization) } \\
\text { 1,300 (carbonization) }\end{array}$ & $\begin{array}{l}\text { The process can be } \\
\text { run in a single reactor } \\
\text { with temperature zones } \\
\text { ranging from } 1,500 \text { to } \\
300\end{array}$ & $\begin{array}{c}(\text { min. }>600) \\
\text { For wastes with } \mathrm{Cl} \\
\text { content } \\
<1 \%->850, \text { for } \\
\text { hazardous wastes }-> \\
1,050\end{array}$ \\
\hline $\begin{array}{l}\text { Process energy } \\
\text { balance }\end{array}$ & Endoenergic & \multicolumn{2}{|c|}{ Endo- or exoenergic } & Exoenergic \\
\hline \multirow{4}{*}{ Gas products } & \multicolumn{4}{|c|}{ Composition } \\
\hline & Water vapor: $\mathrm{H}_{2} \mathrm{O}$ & $\begin{array}{c}\mathrm{CO}_{2}, \mathrm{CO}, \mathrm{CH}_{4} \\
\mathrm{C}_{\mathrm{n}} \mathrm{H}_{\mathrm{m}}, \mathrm{H}_{2}, \mathrm{H}_{2} \mathrm{~S}\end{array}$ & $\begin{array}{c}\mathrm{CO}_{2}, \mathrm{CO}, \mathrm{CH}_{4}, \mathrm{H}_{2}, \mathrm{H}_{2} \mathrm{O} \\
\mathrm{N}_{2},\left(\text { byproducts: } \mathrm{C}, \mathrm{CS}_{2},\right. \\
\mathrm{S}_{2} \mathrm{COS}, \mathrm{NH}_{3}, \mathrm{H}_{2} \mathrm{~S}, \\
\mathrm{HCN}, \mathrm{NO}, \mathrm{SO}_{2} \text { ) }\end{array}$ & 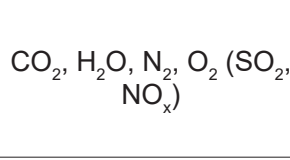 \\
\hline & \multicolumn{4}{|c|}{ Application } \\
\hline & - & Combustible pyrolytic gas & $\begin{array}{l}\text { Combustible process } \\
\text { gas for boilers, gas } \\
\text { turbines and piston } \\
\text { engines; substrate for } \\
\text { synthesis of methanol, } \\
\text { liquid synthetic fuels, } \\
\text { ammonia, etc. }\end{array}$ & Non-combustible \\
\hline \multirow{4}{*}{ Liquid products } & \multicolumn{4}{|c|}{ Composition } \\
\hline & None & $\begin{array}{c}\text { Water-tar-oil fraction }\left(\mathrm{H}_{2} \mathrm{O}\right. \\
\text { to be bled })\end{array}$ & $\begin{array}{l}\text { None (certain quantity } \\
\text { of tar to be removed } \\
\text { from the gaseous } \\
\text { phase (cooling) } \\
\text { containing benzene, } \\
\text { naphthalene, toluene, } \\
\text { phenols, heterocyclic } \\
\text { compounds, etc.) }\end{array}$ & $\begin{array}{c}\text { None (possible } \\
\text { condensation of water } \\
\text { vapor contaminated } \\
\text { as a result of flue gas } \\
\text { cooling) }\end{array}$ \\
\hline & \multicolumn{4}{|c|}{ Application } \\
\hline & - & Liquid fuel & - & - \\
\hline \multirow{4}{*}{ Solid products } & \multicolumn{4}{|c|}{ Composition } \\
\hline & $\begin{array}{l}\text { Material of non- } \\
\text { modified chemical } \\
\text { composition (adverse } \\
\text { reactions) and reduced } \\
\text { water quantity }\end{array}$ & $\begin{array}{c}\text { Carbonating agent }(\mathrm{C}) \\
\text { and mineral components }\end{array}$ & $\begin{array}{l}\text { Ash (mineral } \\
\text { components) }\end{array}$ & $\begin{array}{l}\text { Ash (mineral } \\
\text { components) }\end{array}$ \\
\hline & \multicolumn{4}{|c|}{ Application } \\
\hline & $\begin{array}{l}\text { Reduced volume, fuel } \\
\text { with higher relative } \\
\text { calorific value }\end{array}$ & $\begin{array}{l}\text { Combustible carbonating } \\
\text { agent, fuels, soot } \\
\text { substitute for industrial } \\
\text { processes, absorbent } \\
\text { precursors, coking mix } \\
\text { ingredient, inks for } \\
\text { printers, etc.. }\end{array}$ & Non-combustible & Non-combustible \\
\hline
\end{tabular}



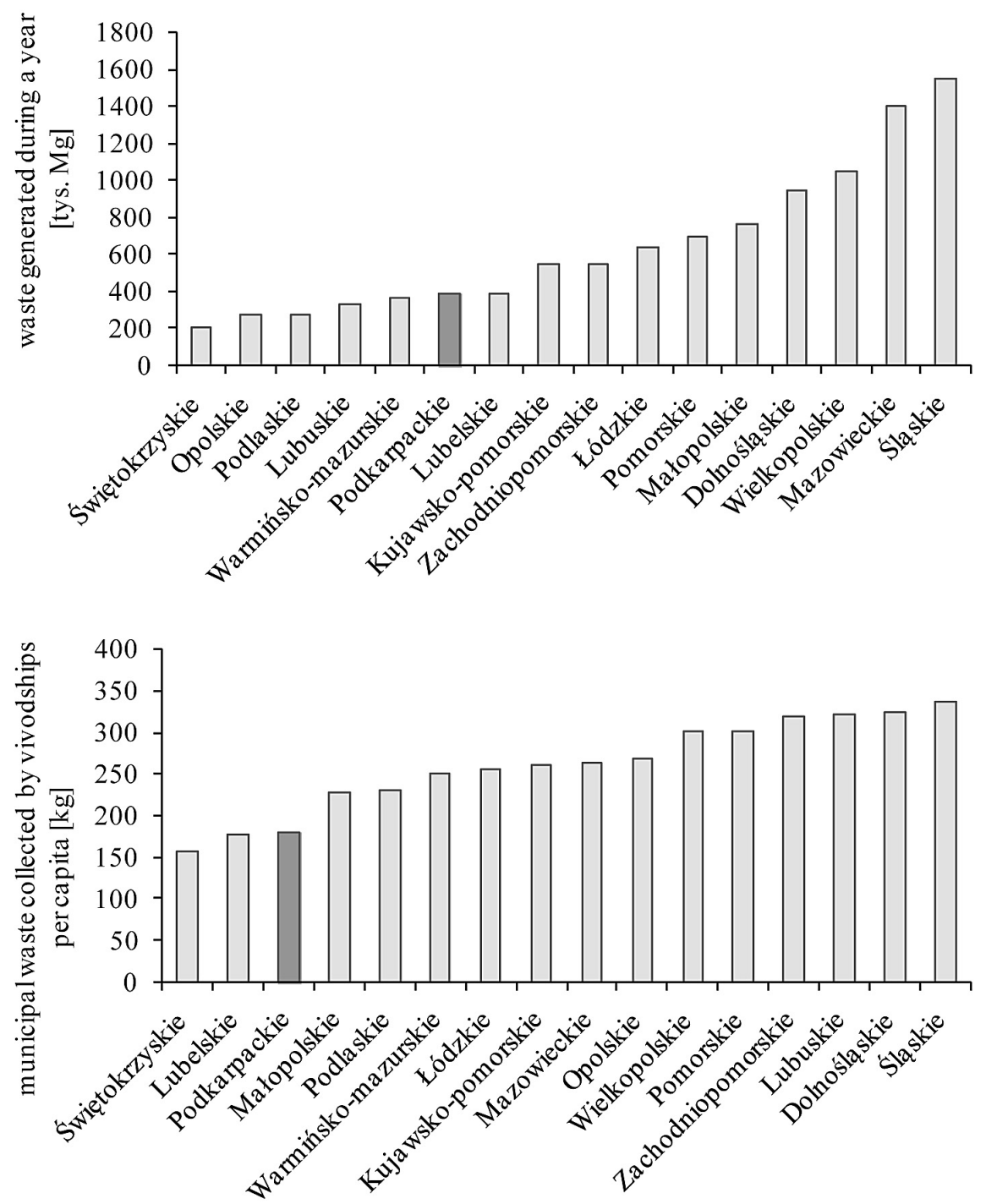

Figure 4. Quantity of municipal waste produced* in 2014 by Polish provinces (top) and per capita yearly quantity of mixed municipal waste (bottom); Sub-Carpathia indicated by the dark bar [GUS 2015b]

* As of 2014, waste collected from all the population is considered as "produced" because municipal waste management systems was extended on all real estate owners on 01/07/2013.

- Combustion of products of natural methanogenesis taking place on dumps. This approach - though adopted by plants equipped with degassing systems, typically in the form of co-generation - was heavily crippled, from the time perspective, by the Regulation by the Minister of Environment of 11/09/2012 on mechanical and biological processing of mixed municipal waste [Dz.U. 2012 poz. 1052]. The Regulation, now rescinded, has resulted in the appearance of many plants for oxygenic stabilization of the screen undersize fraction $<80 \mathrm{~mm}$, which oxidize organic matter contained in waste to carbon dioxide - with negative energy balance (due to energy consumption by heap ventilation systems) and without useful products (the existing products are just dumped).

- Combustion of products of methanogenesis of the biodegradable fraction isolated from the stream of municipal waste before dumping, in dedicated fermentation chambers. According to the Regulation, the process was an alternative method for stabilizing the screen undersize fraction isolated from mixed municipal waste but, in practice, it was never implemented due to higher engineering sophistication and, hence, cost of the system. This method is often applied to sewage sludge by larger municipal liquid waste treatment plants.

- Direct combustion of wastes or products of thermal waste processing (Table 1). Ac- 
cording to the foregoing regulations and the "procedural hierarchy", this method is an alternative to just dumping waste and should be applied to wastes that cannot be disposed of otherwise. Note, however, that heavier waste processing before combustion - such as selective collection, sorting or, specifically, biological decomposition of organic matter - depletes energy stored in the waste [Jaglarz and Generowicz 2015].

Based on literature on the structure of wastes in Rzeszow [Wójcik 2008, Wójcik 2014, Wójcik 2015] and on the range of mean combustion heat values obtained for each waste fraction we can attempt to estimate the energy potential of the wastes (Table 2).

The existing population of Rzeszow, producing $342 \mathrm{~kg}$ of waste per capita per year, can provide $64,290,626.4 \mathrm{~kg}$ of waste. The aggregate calorific values of wastes are as follows: $7 * 10^{8}$ to $1 * 10^{9} \mathrm{MJ}$ for screen undersize fraction (heat sufficient for a 8.9-12.7 MW power unit, assuming $40 \%$ efficiency); $9 * 10^{8}$ to $2 * 10^{9} \mathrm{MJ}$ for screen oversize fraction $(10.8-22.9 \mathrm{MW}) ; 8 * 10^{8}$ to $1 * 10^{9}$ MJ for mixed waste (9.9-18.3 MW).

Note, however, that these figures can be seriously miscalculated due to significant variability of waste fraction shares over the year, issues related to accurate determination of weights of various plastics (carrying different calorific values) and varying content of water (particularly in mixed waste).

The foregoing results represent a small fraction of the power-generating capacity used by
Rzeszow. The Rzeszow Cogeneration Plant generates $101 \mathrm{MWe}$ and more than $76 \mathrm{MWt}$ from the gas-steam (gas turbine) unit, 29 MWe and 26 MWt from 4 sets of piston motors and almost 400 MWe from 6 stoker-fired and pulverized-fuel boilers, which, in aggregate, makes almost $130 \mathrm{MWe}$ and $500 \mathrm{MWt}$ [www.ecrzeszow.pgegiek.pl].

However, seen from the perspective of the $3 \mathrm{E}$ and SWOT analyses, the thermal conversion of waste in Rzeszow can provide additional benefits (Table 3 ).

\section{CONCLUSION}

While studying prospects for the thermal waste conversion in the Sub-Carpathia, we noted important differences between Rzeszow and the rest of the province. Rzeszow produces waste in relatively high concentration, comparable to other big cities. On the other hand, the province as a whole has one of the smallest waste concentration rates in Poland, which is a consequence of its demographic and economic profiles (types of developments, working population, jobs, personal income, etc.). These affect the quantity and quality of waste. However, the conversion should not be viewed solely in terms of its energy balance; indeed, it would have a small share in meeting the overall demand. The screen oversize fraction contained in waste offers the best energy performance, while converting it to energy would relieve space on existing dumps and, hence, reduce the environmental costs of storing waste.

Table 2. Theoretical maximum and minimum calorific values [Rand et al. 2000, Jaglarz and Generowicz 2015] and municipal waste fraction shares in Rzeszow [Wójcik 2008, Wójcik 2014, Wójcik 2015]. The table does not account for such fractions as metals or glass because of their irrelevance for combustion.

\begin{tabular}{|l|c|c|c|c|}
\hline \multirow{2}{*}{ Qualitative waste fraction } & \multirow{2}{*}{$\begin{array}{c}\text { Calorific value } \\
\text { MJ/kg }\end{array}$} & \multicolumn{2}{c|}{ The proportion of fraction in the waste } \\
\cline { 3 - 5 } & $15-20$ & 0.1626 & 0.159 & 0.1709 \\
\hline Plant food waste & $0-20$ & 0.0133 & 0.0077 & 0.0187 \\
\hline Animal food waste (including bones) & $22-42$ & & & \\
\hline $\begin{array}{l}\text { Plastics together } \\
\text { and examples of components }\end{array}$ & 45 & & & 0.2275 \\
PE & $15-25$ & 0.0794 & 0.3708 & \\
PVC & 40 & & & 0.0411 \\
PS & 45 & & & 0.1799 \\
PP & $16-19$ & 0.0119 & 0.0416 & n.d. \\
\hline Fabrics & $16-26$ & 0.0862 & 0.2128 & 0.029 \\
\hline Paper and cardboard & $20-25$ & n.d. & n.d. & 0.1587 \\
\hline Leather and rubber & $15-20$ & 0.0578 & 0.0481 & 0.0514 \\
\hline Organics & 15 & 0.3287 & & \\
\hline Remains (10-12mm screen) & & &
\end{tabular}


Table 3. SWOT analysis for waste-to-energy conversion in the Sub-Carpathia and in Rzeszow

\begin{tabular}{|c|c|}
\hline Opportunities & Threats \\
\hline $\begin{array}{l}\text { - Deepening energy crisis } \\
\text { - Search for alternative sources of energy for improvement } \\
\text { of the energy supply security of Poland } \\
\text { - New technologies for purification and combustion of } \\
\text { gaseous products }\end{array}$ & $\begin{array}{l}\text { - Shaky waste management policies of the central } \\
\text { government } \\
\text { - Chaotic energy policy of the state } \\
\text { - Depopulation (less waste) } \\
\text { - Low employment and salaries in the province (less highly } \\
\text { calorific packing materials) } \\
\text { - Demand for a dump site for the post-combustion inert } \\
\text { fraction } \\
\text { - Growing share of PVC in wastes }\end{array}$ \\
\hline Strengths & Weaknesses \\
\hline $\begin{array}{l}\text { - Continued population / city limits growth } \\
\text { - Growth of per capita waste production } \\
\text { - Significantly higher concentration of waste in Rzeszow } \\
\text { - Existing base for electric and thermal energy generation } \\
\text { using conventional methods (mainly obsolete combustion } \\
\text { technologies) and improved filtering methods (end of pipe) } \\
\text { with substantial diversification of sources of energy (units) } \\
\text { and with potential for co-generation }\end{array}$ & $\begin{array}{l}\text { - No public support } \\
\text { - Still poor efficiency of waste sorting at the source (public } \\
\text { ignorance and/or lack of motivation) } \\
\text { - No coherent framework for negotiating municipal and } \\
\text { - Lower utility projects with the public } \\
\text { - Low rate of waste accumulation in the region } \\
\text { individual municipalities and counties } \\
\text { - Hitherto poor efficiency of selective collection }\end{array}$ \\
\hline
\end{tabular}

\section{REFERENCES}

1. Chen P., Xie Q., Addy M., Zhou W., Liu Y., Wang Y., Cheng Y., Li K., Ruan R. 2016. Review Utilization of municipal solid and liquid wastes for bioenergy and bioproducts production. Bioresour Technol, 215, 163-172.

2. Dahlquist E., Vassileva I., Wallin F., Thorin E., Yan J. 2011. Optimization of the energy system to achieve a national balance without fossil fuels. Int J Green Energy, 8, 684-704.

3. Jaglarz G., Generowicz A. 2015. Charakterystyki energetyczne odpadów komunalnych po procesach odzysku i recyklingu. Ekonomia i Środowisko, 2, 154-165.

4. Johari A., Ahmed S.I., Hashim H., Alkali H., Ramli M. 2012. Economic and environmental benefits of landfill gas from municipal solid waste in Malaysia. Renew Sustain Energy Rev, 16, 2907-2912.

5. Johri R., Rajeshwari K.V., Mullick A.N. 2011. Technological option for municipal solid waste management. In: Wealth from Waste: Trends and Technologies. LaL B., Priyangshu M.S. (ed.) TERI Press, 342-378.

6. Jurczyk Ł., Koc-Jurczyk J. 2014. Zmiany podejścia do składowania odpadów a generowanie odcieków składowiskowych. Archiwum Gospodarki Odpadami i Ochrony Środowiska, 16, 31-40.

7. Kostecka J. 2013. Self evaluation on the way to retardation of pace of life and resources transformation. Problems of Sustainable Development, 8(2), 93-102.

8. Kostecka J., Koc-Jurczyk J., Garczyńska M. 2016. Rozważania na temat zrównoważonej gospodarki odpadami. Polish Journal for Sustainable Development, 20, 105-117. DOI: 10.15584/ pjsd.2016.20.12.
9. Ng W.P.Q., Lam H.L., Varbanov P.S., Klemeš J.J. 2014. Waste-to-Energy (WTE) network synthesis for Municipal Solid Waste (MSW). Energy Convers Manage, 85, 866-874.

10. Noor Z.Z., Yusuf R.O., Abba A.H., Abu Hassan M.A., Mohd Din M.F. 2013. An overview for energy recovery from municipal solid wastes (MSW) in Malaysia scenario. Renew Sustain Energy Rev, 20, 378-384.

11. Tan S.T., Ho W.S., Hashim H., Lee C.T., Taib M.R., Ho C.S. 2015. Energy, economic and environmental (3E) analysis of waste-to-energy (WTE) strategies for municipal solid waste (MSW) management in Malaysia. Energ Conversi Manage, 102, 111-120.

12. Tan S.T., Lee C.T., Hashim H., Ho W.S., Lim J.S. 2014. Optimal process network for municipal solid waste management in Iskandar Malaysia. J Clean Prod, 71, 48-58.

13. Tanaka M. 2014. Municipal solid waste management in Japan. In: Pariatamby A., Tanaka M. (ed.) Municipal solid waste management in Asia and the Pacific Islands, Springer Singapore, 157-171.

14. Wójcik W. 2014. Charakterystyka odpadów komunalnych w oparciu o badania morfologiczne odpadów dla miasta Rzeszowa. In: Interdyscyplinarne zagadnienia $\mathrm{w}$ inżynierii i ochronie środowiska. Tom 4. Traczewska T.M., Kaźmierczak B. (ed.) Oficyna Wydawnicza Politechniki Wrocławskiej, Wrocław. 994-1013.

15. Wojdyga K., Chorzelski M., Mirosz L., Wagner R. 2014. Przyszłość to odpad i kogeneracja. Energetyka Cieplna i Zawodowa, 4, 66-71.

16. Nadziakiewicz J., Wacławiak K., Stelamch S. 2012. Procesy termiczne utylizacji odpadów. Wydawnictwo Politechniki Śląskiej, Gliwice. 
17. Rand. T., Haukohl J., Marxen U. 2000. Municipal Solid Waste Incineration: Requirements for a Successful Project. World Bank Technical Paper No. 462.

18. European Commission (EC) Directive 2008/98/EC of the European Parliament and of the Council of 19 November 2008 on waste and repealing certain Directives (Waste Framework Directive).

19. Rozporządzenie Ministra Środowiska z dnia 11 września 2012 r. w sprawie mechaniczno-biologicznego przetwarzania zmieszanych odpadów komunalnych (Dz.U. 2012 poz. 1052).

20. Ustawa z dnia 14 grudnia 2012 r. o odpadach (Dz.U. 2013 poz. 21).

21. Biuletyn Statystyczny Województwa Podkarpackiego I kwartał 2015. GUS 2015a.

22. Ochrona Środowiska 2015. GUS 2015b.

23. Plan Gospodarki Odpadami dla województwa podkarpackiego. Podkarpackie Biuro Planowania
Przestrzennego. Rzeszów 2012.

24. Wójcik B. Plan gospodarki odpadami dla miasta Rzeszowa na lata 2008 - $2011 \mathrm{z}$ uwzględnieniem lat 2012 - 2015. Rzeszów 2008

25. Wójcik B. Oznaczenie składu morfologicznego odpadów pochodzących z Miasta Rzeszowa, Dębica - Rzeszów, Sprawozdania z lat 2009-2012. Rzeszów 2013.

26. www.avfallsverige.se: Swedish waste management association. Towards a greener future with Swedish. Waste-to-energy. Malmo, 2014. (date of entry 08.10.2016).

27. www.ec.europa.eu Municipal waste generation and treatment, by type of treatment method.http://epp. eurostat.ec.europa.eu/tgm/refreshTableActiondo?t $\mathrm{ab}=$ table \&plugin $=1 \&$ pcode $=$ tsdpc $240 \&$ language $=$ en (date of entry 08.06.2016).

28. www.ecrzeszow.pgegiek.pl (date of entry 08.09.2016). 